\title{
In the land of giants: the legacy of José Dantas de Souza Leite
}

\author{
Na terra de gigantes: o legado de José Dantas de Souza Leite \\ Hélio A. G. Teive', Plínio M. Lima', Francisco M.B. Germiniani', César L. Boguszewski²
}

\begin{abstract}
The authors describe the extraordinary contribution to science made by José Dantas de Souza Leite, who graduated from the Bahia School of Medicine and trained in Prof. Charcot's Neurology Service under the supervision of Charcot's most able pupil, Dr. Pierre Marie. Souza Leite presented his doctoral thesis on acromegaly, in Paris in 1890, and in the following year both him and Pierre Marie published a book on the subject, "Essays on Acromegaly". This exceptional work established Souza Leite internationally as an important researcher, and the first Brazilian physician to contribute to the development of neuroendocrinology in an innovative way.
\end{abstract}

Keywords: history, neurology, endocrinology, acromegaly, gigantism, pituitary gland.

\section{RESUMO}

Os autores apresentam a extraordinária contribuição científica do Dr. José Dantas de Souza Leite, médico formado pela Faculdade de Medicina da Bahia, e interno do Serviço de Neurologia do Professor Charcot, onde estagiou sob supervisão do seu melhor discípulo, Pierre Marie. Souza Leite apresentou a sua tese de doutoramento em Paris sobre acromegalia, no ano de 1890. Um ano mais depois, publicou o livro "Essays on Acromegaly" em coautoria com Pierre Marie. Este trabalho excepcional consagrou Souza Leite como grande pesquisador no cenário internacional e o primeiro médico brasileiro a contribuir de maneira inovadora para o desenvolvimento da neuroendocrinologia mundial.

Palavras-chave: história, neurologia, endocrinologia, acromegalia, gigantismo, hipófise.

In the $19^{\text {th }}$ century the Salpêtrière Hospital in Paris, France, became recognized throughout the world as a centre of excellence in Neurology. Under the leadership of Prof. Jean-Martin Charcot, considered the father of modern Neurology, the Neurology School at Salpêtrière began to welcome large numbers of physicians with an interest in Neurology from different parts of the world, including Brazil ${ }^{1}$. Following his graduation from the Bahia School of Medicine, in Northeast Brazil, Dr. José Dantas de Souza Leite was one of the Brazilian physicians who was granted a fellowship to study in Prof. Charcot's service ${ }^{2,3}$. The aim of this paper is to review his fundamental contribution to neuroendocrinology as one of the first physicians at the time to acknowledge acromegaly as a new clinical condition,

\section{SOUZA LEITE - A SHORT BIOGRAPHY}

José Dantas de Souza Leite was born on 10 May 1859, in the town of Santa Luzia, in the state of Sergipe, Northeast
Brazil. (Figure 1). He graduated in Medicine in 1880 from the Bahia School of Medicine, the first medical school in Brazil $^{2,3}$. The title of his graduation thesis was "Morbid inheritance" ${ }^{2}$. Souza Leite later moved to France, where he again graduated in Medicine, this time from the Faculté de Medicine in Paris ${ }^{2,3}$. Following that, he began to attend Prof. Charcot's service at the Salpêtrière Hospital and became a disciple of Charcot's most famous pupil, Pierre Marie $^{2,3}$. Under Pierre Marie's supervision Souza Leite completed his doctoral thesis "De l'acromégalie: maladie de Marie" in $1890^{2,3,4}$. Souza Leite also trained at the Bicêtre Hospital in Paris and was a member of various scientific societies, including the Anthropological Society of London and the Medico-Psychological Association ${ }^{2,3}$. He returned to Brazil in 1890, settling at first in Salvador and then later moving to Rio de Janeiro, where he published various studies on Neurology and would ultimately die in 1925 , at the age of $66^{2}$.

\footnotetext{
1Universidade Federal do Paraná, Hospital de Clínicas, Departamento de Clínica Médica, Serviço de Neurologia, Curitiba PR, Brazil; ¿Universidade Federal do Paraná, Hospital de Clínicas, Departamento de Clínica Médica, Serviço de Endocrinologia, Curitiba PR, Brazil. Correspondence: Hélio A G Teive; Rua General Carneiro, 1103/102;80060-150 Curitiba PR, Brasil; E-mail: hagteive@mps.com.br Conflict of interest: There is no conflict of interest to declare.

Received 08 February 2015; Accepted 02 March 2015
} 


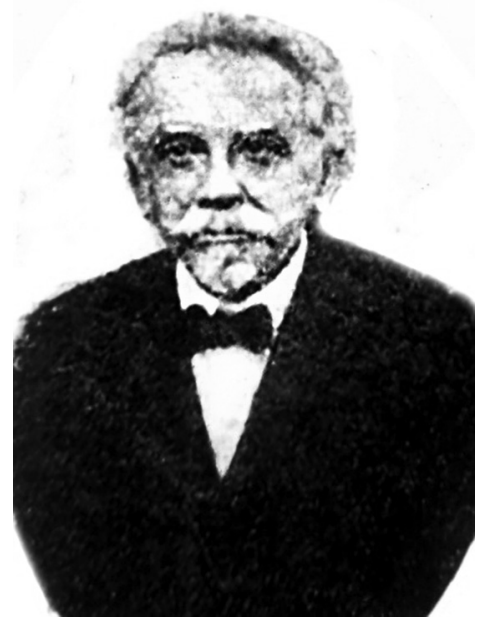

Figure 1. José Dantas de Souza Lima (1859-1925). (This picture was kindly given by Prof. Dr. Thomaz Rodigues Porto da Cruz from the Federal University of Bahia).

\section{MARIE'S ACROMEGALY}

In 1886, Pierre Marie published a report of two cases of a 37-year-old woman and 54-year-old woman with acromegaly ("Sur deux cas d' acromégalie: hypertrophie singulière non congénitale des extrémités supérieures, inférieures et céphalique")5. This was the first detailed clinical description of the disease, which had already been investigated by other authors, but lacked a proper definition ${ }^{5,6}$. It was in this article that Marie used the term acromegaly for the first time ("A condition characterized by hypertrophy of the hands, feet and face exists which we propose to call 'acromegaly', which means hypertrophy of the extremities") $)^{5}$.Marie published further studies on acromegaly in the period between 1888 and 1890; and in 1891, in joint authorship with Marinescu, published a study of the pathological anatomy of the disease, in which an enlarged pituitary gland was defined as a hallmark of the condition ${ }^{7.8}$. In 1890, Marie suggested to Souza Leite, who was at that time training at Prof. Charcot's service under Maries direct supervision, that he should write his doctoral thesis on acromegaly ${ }^{3,4}$. Souza Leite defended his thesis in $1890^{4}$, which was published in 1891 by The New Sydenham Society of London in a version translated by Dr. Procter S. Hutchinson'. The book, jointly authored by Marie and Souza Leite, was published under the title "Essays on Acromegaly" and is divided into three chapters. In the first chapter Marie presents his original description of the disease under the title "Two cases of acromegaly: an usual non-congenital hypertrophy of the head and upper and lower extremities". In the introduction Marie clearly states where the study was carried out: "The two cases which are the subject of this article were observed in Professor Charcot's clin$i c$ "9. In the same chapter Marie describes eight cases of acromegaly investigated by other authors. ${ }^{9}$. At the end of this chapter he draws two conclusions related to acromegaly: 1) "There exists a disease specially characterized by a hypertrophy of the hands, feet and face, which we propose to call acromegaly"; and 2) "Acromegaly is quite distinct from myxedema, and from Paget's disease, as well as from leontiasis ossea of Virchow".

\section{SOUZA LEITE'S THESIS - ON ACROMEGALY ("MARIE'S DISEASE")}

Souza Leite's thesis was published as the second chapter of the book, under the title " $A$ Thesis on acromegaly (Marie's Malady)" . In the introduction to this chapter, Souza Leite wrote "To Dr. Pierre Marie is due the merit for recognizing it as a distinct malady and of describing it in such a manner

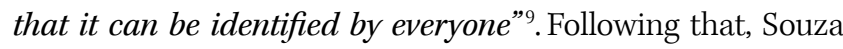
Leite describes the clinical picture of patients with acromegaly very comprehensively (Figure 2), emphasizing the presence of headache, menstrual irregularities, reduced libido and visual disturbances 9 . He also discusses the evolution of the disease, differential diagnosis, prognosis and treatment and even describes a pioneering study of the pathological anatomy of the condition'. His description of the latter, based mainly on the results of seven autopsies, is very detailed: "The most specific of these lesions, one which may be considered as essential, since it has not been found absent, is the considerable increase in size of the pituitary body. This gland is changed into a hypertrophied mass, of which the size varies from that of a pigeon's egg to that of a hen's egg, or even an apple" . (Figure 3) Finally, in the last part of the chapter, Souza Leite introduces all the cases of acromegaly studied up to then; eight of these had been investigated at the Neurology Service of the Salpêtrière Hospital and thirty in other services, summing up to a total of thirty-eight patients studied 9 . An additional list of ten cases of acromegaly that had been published in the literature was also included ${ }^{9}$. After publication of the book, acromegaly, which had previously been known as Marie’s disease, became known worldwide and Souza Leite's innovative contribution to the initial description of the disease was internationally recognized., ${ }^{3,9,10}$

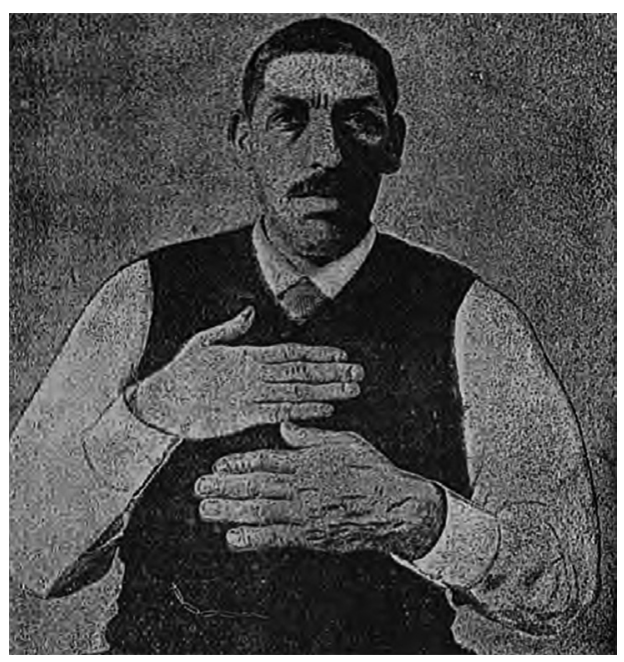

Figure 2. Patient with acromegaly. (Extracted from Souza Leite's thesis, 1890). 


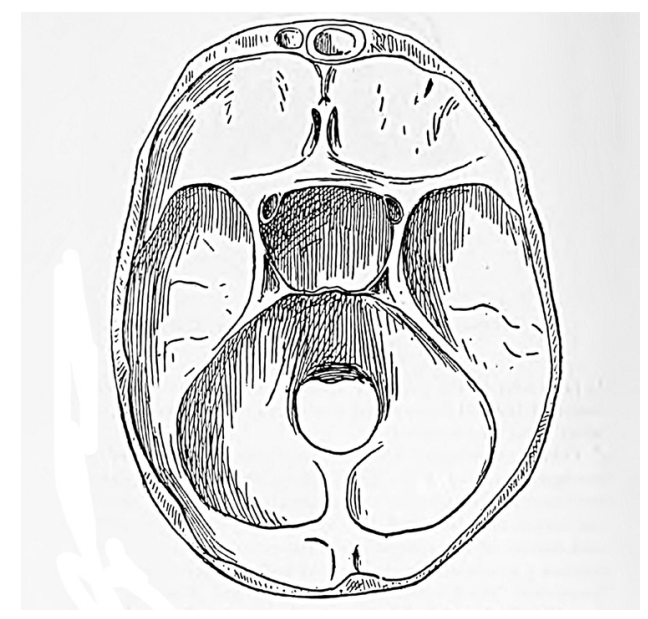

Figure 3. Acromegaly - Anatomic and pathologic findings: enlarged sella turcica due to a tumor/lesion of the pituitary gland. (Extracted from Souza Leite's thesis, 1890).

\section{CONCLUSION}

José Dantas de Souza Leite, following his graduation from the Bahia School of Medicine, trained in Prof. Charcot's Neurology Service under the supervision of Pierre Marie. Souza Leite defended his doctoral thesis in Paris in 1890, and in 1891, along with Pierre Marie, published a book with detailed descriptions of a cohort of patients with acromegaly. This exceptional work established Souza Leite internationally as an important researcher in the field of neuroendocrinology $y^{3,6,9,10}$. In 2014, the Brazilian Society of Endocrinology and Metabolism created, and granted for the first time, the "José Dantas de Souza Leite Award" to be given to a Brazilian researcher recognized by his or her scientific contribution to the development of Endocrinology.

\section{References}

1. Teive HAG, Almeida SM, Arruda WO, Sá DS, Werneck LC Charcot and Brazil. Arq Neuropsiquiatr. 2001;59(2A):295-9. http://dx.doi.org/10.1590/S0004-282X2001000200032

2. José Dantas Souza Leite. In: Leite G Médicos ilustres da Bahia e do Sergipe. 2011 Feb [cited 2015, Fev, 08]. Salvador: Geraldo Leite; 2011. Available from: http://medicosilustresdabahia.blogsppot. com.br/2011/02/178- jose-dantas-souza-leite.html (2015; Feb, 08).

3. Medvei VC. The history of clinical endocrinology: a comprehensive account of endocrinology from earliest times to the present day. 2nd rev ed. New York: The Parthenon; 1993.

4. Leite JDS. De l'acromégalie. Paris: Maladie de Marie; 1890.

5. Marie P. Sur deux cas d'acromégalie: hypertrophie singulière non congénitale des extrémités supérieures, inférieures et céphalique. Revue Med Paris. 1886;6:297-333.
6. Herder WW. Acromegaly and gigantism in the medical literature: case descriptions in the era before and the early years after the initial publication of Pierre Marie (1886). Pituitary. 2009;12(3):236-44. http://dx.doi.org/10.1007/s11102-008-0138-y

7. Marie P. De l'acromégalie. Bull Méd Paris. 1889;3:1579-81.

8. Marie P, Marinescu G. Sur l'anatomie pathologique de l’acromégalie. Arch de Méd Expér Anat Path. 1891;3:539-63.

9. Marie P, Leite JDS. Essays on acromegaly. London: New Sydenham Society; 1891.

10. Loriaux DL. Pierre Marie (1853-1940). Endocrinologist. 2007;17(5):243. http://dx.doi.org/10.1097/TEN.0b013e3181565772 